Original Research Article

\title{
Evaluation of nephroprotective activity of Tinospora cordifolia against gentamicin induced nephrotoxicity in albino rats: an experimental study
}

\author{
Monica Sharma, Jyoti Pundir*, Pinki Vishwakarma, Raj Kumar Goel, \\ Manish Saini, K. K. Saxena
}

Department of Pharmacology, LLRM Medical College, Meerut, Uttar Pradesh, India

Received: 29 March 2019

Revised: 11 April 2019

Accepted: 03 May 2019

*Correspondence to:

Dr. Jyoti Pundir,

Email:

jyotipundir044@gmail.com

Copyright: () the author(s), publisher and licensee Medip Academy. This is an openaccess article distributed under the terms of the Creative Commons Attribution NonCommercial License, which permits unrestricted noncommercial use, distribution, and reproduction in any medium, provided the original work is properly cited.

\begin{abstract}
Background: Gentamicin induced nephrotoxicity is a major contributor to Acute Kidney Injury (AKI) resulting from free radicals induced oxidative stress. Tinospora cordifolia is an Indian medicinal plant, widely used because of its antioxidant activity. Due to limited scientific literature exploring its nephroprotective potential, the present study was designed to investigate the nephroprotective effect of aqueous extract of Tinospora cordifolia against gentamicin induced nephrotoxicity in albino rats.

Methods: The study was commenced following approval from Institutional Animal Ethical Committee of L.L.R.M. Medical College, Meerut (UP). Twenty four rats were randomised into four groups of six animals each. Total duration of study was 21 days. Group I received normal saline p.o., group II received normal saline along with gentamicin on last 5 days, group III and IV received Tinospora cordifolia in graded doses p.o. along with gentamicin on last 5 days. Injection gentamicin $(40 \mathrm{mg} / \mathrm{kg})$ i.p. was given once daily for last 5 days to induce nephrotoxicity in rats of groups II, III and IV. The rats were sacrificed under anaesthesia, blood samples analysed for blood urea nitrogen (BUN) and serum creatinine levels and histopathological changes were studied. Statistical analysis was done using ANOVA followed by post hoc test.

Results: Tinospora cordifolia pre-treated groups exhibited significant $(\mathrm{p}<0.001)$ limitation in rise in levels of BUN and serum creatinine in a dose dependent manner. Histolopathological observations further corroborated the biochemical findings.

Conclusions: The present study concluded that aqueous extract of Tinospora cordifolia possesses nephroprotective potential against gentamicin induced nephrotoxicity.
\end{abstract}

Keywords: Gentamicin, Nephroprotective, Nephrotoxicity, Tinospora cordifolia

\section{INTRODUCTION}

Acute kidney injury (AKI) is a common clinical complication which is associated with increased morbidity and mortality, affecting about $1-7 \%$ of hospitalised patients and $1-25 \%$ of patients in the intensive care unit (ICU). ${ }^{1,2}$ Multiple epidemiologic investigations have provided a broad range of estimates of the incidence of
AKI in critically ill patients, and the incidence varied between $15 \%$ and $50 \% .{ }^{3}$ Drugs are a common cause of AKI responsible for approximately $20 \%$ of community and hospital acquired episodes of AKI which may reach as high as $66 \%$ in the elderly. ${ }^{4,5}$

Gentamicin is an aminoglycoside antimicrobial agent, effective against a wide range of Gram-negative bacteria and also against Staphylococcus and Enterococcus, 
especially in synergy with $\beta$-lactams. Gentamicin remains a first-line agent for many severe infections. The major drawback of the gentamicin is the risk of nephrotoxicity and ototoxicity. Gentamicin induces nephrotoxicity via nitrosative stress. $^{6}$ It also causes nephrotoxicity by inhibiting protein synthesis in renal cells. This mechanism specifically causes necrosis of cells in the proximal tubule, resulting in acute tubular necrosis which can lead to acute renal failure. ${ }^{7}$

Tinospora cordifolia (T. cordifolia) commonly known as Guduchi, belonging to family Menispermeaceae is well known in Ayurvedic medicine due to its property of healing many diseases. A variety of chemical constituents such as alkaloids, diterpenoid lactones, steroids, glycosides aliphatic compounds and polysaccharides have been isolated, identified and characterized from different parts of $T$. cordifolia. $T$. cordifolia has shown antioxidant, anti-hyperglycaemic, anti-neoplastic, anti-stress, antispasmodic, anti-pyretic, anti-allergic, antileprotic, antiinflammatory and anti-hyperlipidaemic activities in experimental animals. ${ }^{8}$

Due to paucity of scientific literature exploring the nephroprotective action of $T$. cordifolia, the present study was undertaken to investigate the nephroprotective potential of aqueous extract of Tinospora cordifolia against gentamicin induced nephrotoxicity in albino rats.

\section{METHODS}

\section{Experimental animals}

Twenty four healthy Wistar albino rats of either sex, weighing 150-200gm were grouped and housed in polypropylene cages in CPCSEA approved Central Animal House of L.L.R.M. Medical College, Meerut (UP). The rats were maintained under standard laboratory conditions of alternating periods of light and darkness of 12 hours each, temperature $\left(25 \pm 2^{\circ} \mathrm{C}\right)$ and relative humidity (45 to 55\%). The rats had free access to standard rat pellet diet and tap water ad libitum. After one week of acclimatization, the animals were considered suitable for study. Pregnant female rats were not included in the study.

\section{Preparation of plant extract}

The aqueous extract of Tinospora cordifolia (AETC) stem was prepared by taking 100 grams of shade dried and powdered plant material and mixing with $500 \mathrm{~mL}$ of distilled water in a Soxhlet apparatus for 20-24hours. The filtrate was then concentrated in a rotary evaporator and the extract stored at $4^{\circ} \mathrm{C}$ until required.

\section{Drugs and chemicals}

Gentamicin used for inducing nephrotoxicity was the commercially available injectable preparation (Genticyn manufactured by Abbott Healthcare Pvt. Ltd.). Q-Line assay kits for serum urea and creatinine were procured from POCT Services Private Limited, New Delhi, India.

\section{Experimental study design}

The study was commenced after getting approval from Institutional Animal Ethical Committee of L.L.R.M. Medical College, Meerut, India, registered under CPCSEA India. The study was conducted in the Department of Pharmacology, L.L.R.M. Medical College, Meerut (UP) from September 2017 to August 2018.

The total duration of study was 21 days, wherein 24 rats were randomly divided into four groups of six animals each. Drugs were administered per orally to the rats after a fasting period of 4 hours to ensure proper absorption.

Group-I: Control group was given $0.9 \% \mathrm{NaCl}$ solution in a single oral dose of $2 \mathrm{ml} / \mathrm{kg} /$ day for 21 days.

Group-II: In addition to $0.9 \% \mathrm{NaCl}$ solution, the animals of this group received injection gentamicin $(40 \mathrm{mg} / \mathrm{kg})$ intraperitoneally (i.p.) once daily for last 5 days.

Group-III: This group was treated with aqueous extract of Tinospora cordifolia (AETC) in the dose of $250 \mathrm{mg} / \mathrm{kg}$ body weight after making a suspension in normal saline per orally for 21 days. Injection gentamicin $(40 \mathrm{mg} / \mathrm{kg})$ was administered intraperitoneally (i.p.) once daily for last 5 days.

Group-IV: This group was treated with aqueous extract of Tinospora cordifolia (AETC) in the dose of $500 \mathrm{mg} / \mathrm{kg}$ body weight after making a suspension in normal saline per orally for 21 days. Injection Gentamicin $(40 \mathrm{mg} / \mathrm{kg}$ ) was administered intraperitoneally (i.p.) once daily for last 5 days.

After fasting for $24 \mathrm{hrs}$ after the last dose of Gentamicin, with free access to water ad libitum, the rats were sacrificed under anaesthesia produced by intraperitoneal injection of Ketamine $(75 \mathrm{mg} / \mathrm{kg})$ and Xylazine (10 $\mathrm{mg} / \mathrm{kg}$ ). Blood samples for performing biochemical tests were collected from abdominal aorta and the kidneys were dissected out for histopathological study. The collected blood samples were centrifuged at about $2500 \mathrm{rpm}$ for 10 minutes. The serum so separated was used for estimation of BUN and serum creatinine levels using assay kits spectrophotometrically.

Rats from each group were sacrificed and the kidneys were excised for histopathological examination. The kidneys were washed with normal saline. A section of kidney was dissected, fixed in neutral buffered formalin $(10 \%)$ and then dehydrated with grades of ethanol $(70 \%, 80 \%, 90 \%$, $95 \%$ and $100 \%$ ). Dehydration was followed by clearing the samples in xylene. Tissue samples were then embedded in paraffin wax from which blocks were prepared. Sections of $5 \mu \mathrm{m}$ thickness were prepared from the blocks using a microtome. ${ }^{9}$ Tissue samples were 
stained with Haematoxylin and Eosin stain and subjected to histopathological examination.

\section{Statistical analysis}

The study data were expressed as mean \pm standard error of mean (SE). The statistical analysis was carried out using one way analysis of variation (ANOVA) followed by Tukey's post hoc test. p-value $<0.05$ was considered as significant.

\section{RESULTS}

Effect of Tinospora cordifolia on blood urea nitrogen $(B U N)$ and serum creatinine levels
BUN level, as depicted in Table 1, in normal saline treated group was $23.8 \pm 0.52 \mathrm{mg} / \mathrm{dl}$. It was found to be significantly increased $(\mathrm{p}<0.001)$ after administration of gentamicin to $64.42 \pm 0.62 \mathrm{mg} / \mathrm{dl}$. Tinospora cordifolia exhibited a dose dependent limitation of BUN rise after gentamicin administration. At the dose of $250 \mathrm{mg} / \mathrm{kg}$ for 21 days Tinospora cordifolia displayed a highly significant $(\mathrm{p}<0.001)$ prevention in BUN rise $(40.57 \pm 1.54 \mathrm{mg} / \mathrm{dl})$ when compared to gentamicin treated group. However, in the dose of $500 \mathrm{mg} / \mathrm{kg}$ for 21 days the Tinospora cordifolia extract showed much more efficacy, in limiting the BUN rise after gentamicin administration, to $28.92 \pm 1.23 \mathrm{mg} / \mathrm{dl}$, and it was also found to be highly significant $(\mathrm{p}<0.001)$.

Table 1: Effect of Tinospora cordifolia on Gentamicin induced changes in BUN levels (Mean \pm SE) $(n=6)$.

\begin{tabular}{|lll|}
\hline Group & Treatment & BUN (mg/dl), Mean \pm SE \\
\hline I & Normal Saline $(2 \mathrm{ml} / \mathrm{kg}, \mathrm{p} . \mathrm{o})$. & $23.80 \pm 0.52$ \\
\hline II & Normal Saline $(2 \mathrm{ml} / \mathrm{kg}, \mathrm{p} . \mathrm{o})+$. Gentamicin $(40 \mathrm{mg} / \mathrm{kg}$, i.p. $)$ & $64.42 \pm 0.62^{*}$ \\
\hline III & Tinospora cordifolia $(250 \mathrm{mg} / \mathrm{kg}, \mathrm{p}$. o. $)+$ Gentamicin $(40 \mathrm{mg} / \mathrm{kg}$, i.p. $)$ & $40.57 \pm 1.54^{\#}$ \\
\hline IV & Tinospora cordifolia $(500 \mathrm{mg} / \mathrm{kg}$, p.o. $)+$ Gentamicin $(40 \mathrm{mg} / \mathrm{kg}$, i.p. $)$ & $28.92 \pm 1.23^{\#}$ \\
\hline${ }^{*} \mathrm{p}<0.001$ as compared to Normal saline treated group, ${ }^{\#}$ p $<0.001$ as compared to Gentamicin treated group
\end{tabular}

Table 2: Effect of Tinospora cordifolia on gentamicin induced changes in serum creatinine levels $(\mathrm{Mean} \pm \mathrm{SE})(\mathrm{n}=6)$.

\begin{tabular}{|lll|}
\hline Group & Treatment & $\begin{array}{l}\text { Serum creatinine (mg/dl), } \\
\text { Mean } \pm \text { SE }\end{array}$ \\
\hline I & Normal Saline $(2 \mathrm{ml} / \mathrm{kg}$, p.o. $)$ & $0.55 \pm 0.015$ \\
\hline II & Normal Saline $(2 \mathrm{ml} / \mathrm{kg}$, p.o. $)+$ Gentamicin $(40 \mathrm{mg} / \mathrm{kg}$, i.p. $)$ & $1.97 \pm 0.016^{*}$ \\
\hline III & Tinospora cordifolia $(250 \mathrm{mg} / \mathrm{kg}$, p.o. $)+$ Gentamicin $(40 \mathrm{mg} / \mathrm{kg}$, i.p. $)$ & $0.92 \pm 0.024 \#$ \\
\hline IV & Tinospora cordifolia $(500 \mathrm{mg} / \mathrm{kg}$, p.o. $)+$ Gentamicin $(40 \mathrm{mg} / \mathrm{kg}$, i.p. $)$ & $0.63 \pm 0.017 \#$ \\
\hline
\end{tabular}

${ }^{*} \mathrm{p}<0.001$ as compared to Normal saline treated group, ${ }^{*} \mathrm{p}<0.001$ as compared to Gentamicin treated group

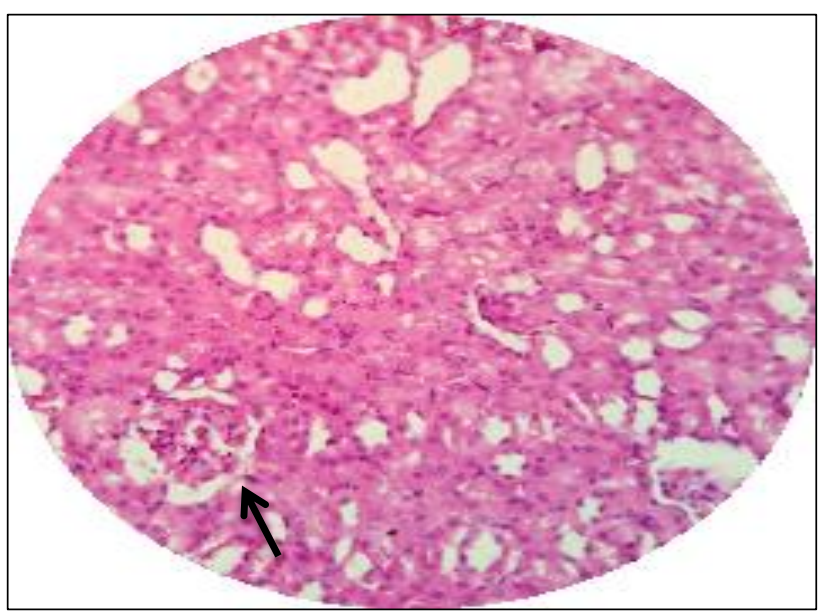

Normal histological architecture of glomerulus (arrow) and renal tubules in rats of control group (Oral saline $2 \mathrm{ml} / 100 \mathrm{~g} /$ day).

Figure 1: Light micrograph of section from kidney stained with Haematoxylin-Eosin (40X).
Creatinine level, as depicted in Table 2, in normal saline treated group was $0.55 \pm 0.015 \mathrm{mg} / \mathrm{dl}$. It was found to be significantly increased $(\mathrm{p}<0.001)$ after administration of gentamicin to $1.97 \pm 0.016 \mathrm{mg} / \mathrm{dl}$. Tinospora cordifolia demonstrated a dose dependent limitation of creatinine rise after gentamicin administration. At the dose of $250 \mathrm{mg} / \mathrm{kg}$ for 21 days Tinospora cordifolia showed a highly significant limitation $(\mathrm{p}<0.001)$ of creatinine rise $(0.92 \pm 0.024 \mathrm{mg} / \mathrm{dl})$ when compared to gentamicin treated group. However, in the dose of $500 \mathrm{mg} / \mathrm{kg}$ for 21 days the Tinospora cordifolia extract had much more efficacy, in limiting the creatinine rise after gentamicin administration, to $0.63 \pm 0.017 \mathrm{mg} / \mathrm{dl}$. This observation was also highly significant $(\mathrm{p}<0.001)$.

\section{Histological studies}

The histopathological sections of kidneys of normal control rats presented with normal morphological appearance of cortex and medulla with normal glomerular 
and tubular stuctures after 21 days (Figure 1). Whereas, in gentamicin treated group the kidney tissue sections of rats revealed haemorrhagic foci, renal tubular degeneration and leucocytic infiltration (Figure 2). The histological sections of kidneys of Tinospora cordifolia treated groups exhibited almost normal architecture of kidney with minimal leucocytic infiltration after 21days of pretreatment (Figure 3), with absence of haemorrhage, tubular casts, glomerular congestion or tubular necrosis. Thus, the nephroprotective effect was confirmed by the histopathological examination of the kidney, wherein the normal cellular architecture was found to be restored.

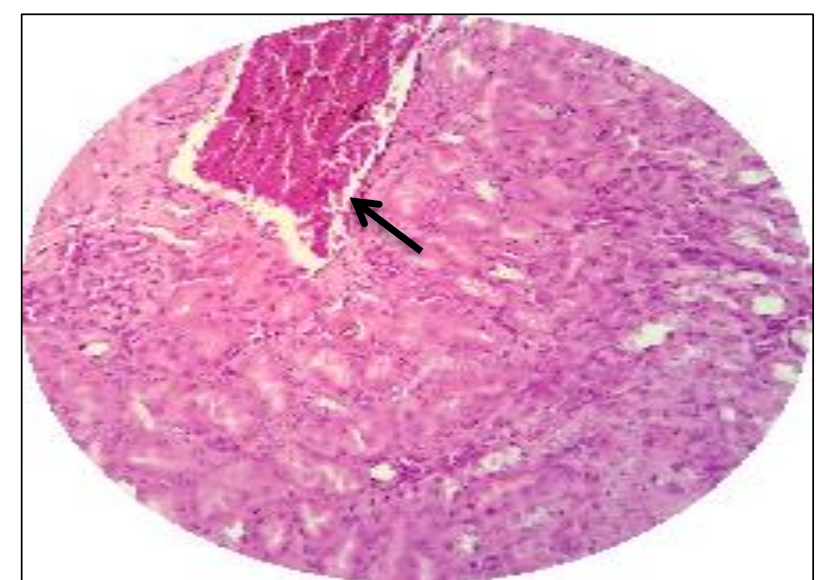

Haemorrhagic foci (black arrow) and renal tubular degeneration (blue arrow) in cortex of rats in Gentamicin group (GT $40 \mathrm{mg} / \mathrm{kg} /$ day i.p. for last 5 days).

\section{Figure 2: Light micrograph of section from kidney} stained with Haematoxylin-Eosin (40X).

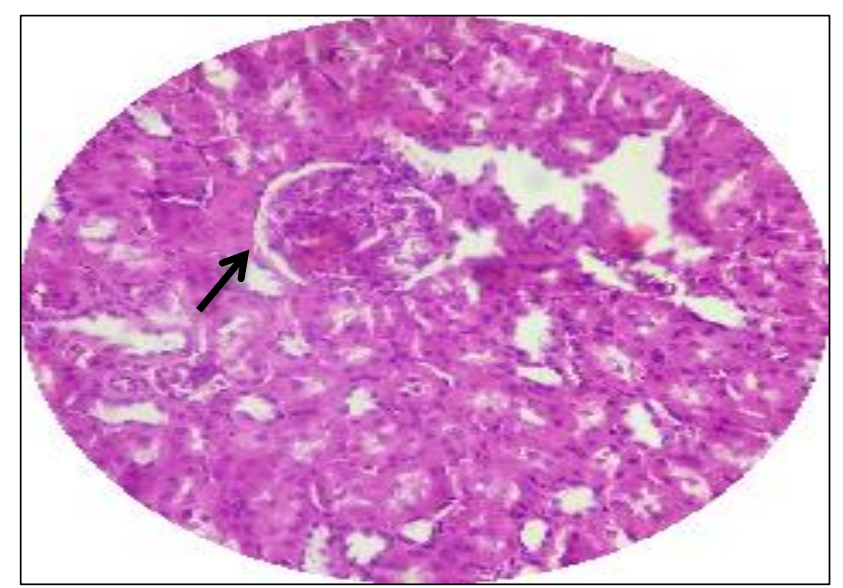

Nearly preserved histological architecture of kidney showing normal glomerulus (arrow) in rats treated with Tinospora cordifolia $(500 \mathrm{mg} / \mathrm{kg} /$ day p.o. for 21 days + Gentamicin $40 \mathrm{mg} / \mathrm{kg} /$ day i.p. for last 5 days).

\section{Figure 3: Light micrograph of section from kidney stained with Haematoxylin-Eosin (40X).}

\section{DISCUSSION}

Nephrotoxicity is a kidney specific feature in which excretion does not go smoothly owing to toxic chemicals or drugs. ${ }^{10,11}$ Renal proximal tubular cells, on account of exposure to toxic levels of drugs in the process of concentration and reabsorption of glomerular filtrate, are highly susceptible to nephrotoxicity. ${ }^{12}$

Nephrotoxicity induced by gentamicin is a commonly used experimental model for evaluation of nephroprotective activity of the drugs. Nephrotoxicity is rapidly induced in rats and presents with established morphological changes and biochemical markers. High doses $(40 \mathrm{mg} / \mathrm{kg}$ or more for gentamicin) are necessary in animals to rapidly induce extended cortical necrosis and overt renal dysfunction. ${ }^{13}$ Therefore, the present study provides an opportunity to evaluate the nephroprotective potential of Tinospora cordifolia by using this model.

Gentamicin (GT), belonging to aminoglycoside group of antimicrobial agents, is actively concentrated in the renal cortex and in proximal tubular cells particularly. After entering the cortical cells it binds to lysosomes with formation of myeloid bodies/secondary lysosomes thus impairing mitochondrial function, interfering with the tubular transport, increasing oxidative stress and forming free radicalswhich is associated with increased lipid peroxidation and decrease in antioxidant enzyme activity in the kidney resulting in renal toxicity. ${ }^{12,6,14}$

General preventive measures against drug induced nephrotoxicity include using alternative available nonnephrotoxic drugs, correcting risk factors, assessing baseline renal function before initiation of therapy, adjusting drug dosage, monitoring renal function and avoiding nephrotoxic drug combinations. ${ }^{15}$

The elevation of BUN and serum creatinine have been used in gentamicin induced nephrotoxicity models as indicator of renal insult and have been found to correlate with extent of injury. ${ }^{16}$ In the present study also, levels of BUN and serum creatinine were evaluated and compared among the 4 groups. Expectedly, the serum creatinine and urea concentrations in the animals of gentamicin treated group were significantly higher than that of the control group. It is an established fact that nephrotoxicity is associated with increased urea in blood. ${ }^{16,17}$ Increased serum creatinine is also strongly related with renal damage. ${ }^{17,18}$ Pre-treatment with Tinospora cordifolia was found to be beneficial in the present study. The levels of BUN and serum creatinine were significantly decreased $(p<0.001)$ in groups treated with this drug as compared to GT group in a dose dependent fashion (Table 1 and Table 2 ). These observations indicate remarkable improvement in renal function.

The results of the serum markers correlated well with the histopathological observations (Figure 1-3) in the renal tissue of animals treated with either GT or test drug or normal saline. It can be inferred from these findings that Tinospora cordifolia afforded significant protection against renal tissue injury. 
A relationship between nephrotoxicity and oxidative stress has been confirmed in many experimental models. ${ }^{19-21}$ Earlier studies have shown that pre-treatment with compounds having antioxidant property prevent gentamicin-induced oxidative stress and renal damage. These include curcumin, garlic extract, melatonin, lycopene ${ }^{16}$ and taurine. ${ }^{22-25}$

The presence of polyphenols and flavonoids with antioxidant potential in methanolic $T$. cordifolia extract (TCE) has earlier been reported by Sivakumar et al. ${ }^{26}$ Reddy et al, documented the protective effect of TCE in reducing lipid peroxidation and protein carbonyl content. ${ }^{27}$ Studies also reveal free radical scavenging properties of $T$. cordifolia. $^{28}$ Kumar et al, from the same department previously stated that aqueous extract of $T$. cordifolia exhibited potent hepatoprotective activity in albino rats due its antioxidant properties. ${ }^{29}$

Gentamicin induced renal injury was evidenced by the elevated biochemical markers [blood urea, serum creatinine] and by the histopathological features of acute tubular necrosis. Pre-treatment with Tinospora cordifolia was found to almost normalize the elevated blood urea, serum creatinine (Table 1 and Table 2) and bring about a marked recovery in kidneys as evidenced microscopically (Figure 1-3).

Hence, it can be concluded that Tinospora cordifolia provides nephroprotection by modulating the antioxidant status of the kidney. T. cordifolia contains many ingredients which have antioxidant property. Whether it is due to one single compound, or all compounds together play a beneficial role remains to be elucidated.

\section{CONCLUSION}

It was concluded from the present study that pre-treatment with Tinospora cordifolia significantly reduced gentamicin induced renal damage. However, further studies are needed to identify and characterize the phytoconstituents from Tinospora cordifolia; and also to explore the exact mechanism by which it acts as nephroprotective agent, before it can be introduced in a clinical setting. The study also carries further scope for assessment of $T$. cordifolia with its other extracts, dose levels, extended test durations and other biochemical parameters, in order to conclusively establish Tinospora cordifolia as a nephroprotective drug.

\section{ACKNOWLEDGEMENTS}

Authors would like to thank Dr Preeti Singh (Associate Professor, Department of Pathology, L.L.R.M. Medical College, Meerut) for her cooperation and sincere help in this study.

Funding: No funding sources

Conflict of interest: None declared
Ethical approval: The study was approved by the Institutional Ethics Committee of L.L.R.M. Medical College, Meerut, India (Approval no. IAEC/2017/1)

\section{REFERENCES}

1. Mendonça A, Vincent JL, Suter PM, Moreno R, Dearden NM, Antonelli M, et al. Acute renal failure in the ICU: risk factors and outcome evaluated by the SOFA score. Intensive Care Med. 2000;26(7):915-21.

2. Nash K, Hafeez A, Hou S. Hospital-acquired renal insufficiency. Am J Kidney Dis. 2002;39(5):930-36.

3. Case J, Khan S, Khalid R, Khan A. Epidemiology of acute kidney injury in the intensive care unit. Crit Care Res Pract. 2013;2013:479730.

4. Kaufman J, Dhakal M, Patel B, Hamburger R. Community-acquired acute renal failure. Am J Kidney Dis. 1991;17(2):191-98.

5. Kohli HS, Bhaskaran MC, Muthukumar T, Thennarasu K, Sud K, Jha V et al. Treatment-related acute renal failure in the elderly: a hospital-based prospective study. Nephrol Dial Transplant. 2000;15(2):212-17.

6. Dhanarajan R, Abraham P, Issac B. Protective effect of ebselen, a selenoorganic drug, against gentamicininduced renal damage in rats. Basic Clin Pharmacol Toxicol. 2006;99(3):267-72.

7. Sundin DP, Meyer C, Dahl R, Geerdes A, Sandoval R, Molitoris BA. Cellular mechanism of aminoglycoside tolerance in long-term gentamicin treatment. Am J Physiol. 1997;4(1):1309-18.

8. Singh SS, Pandey SC, Srivastava S, Gupta VS, Patro B, Ghosh AC. Chemistry and medicinal properties of Tinospora cordifolia (Guduchi). Indian J Pharmacol. 2003;35(2):83-91.

9. Talib VH. A handbook of medical laboratory technology. 2nd Ed. New Delhi: CBS Publishers and Distributers; 2007:155-67.

10. Finn W, Porter G. Urinary biomarkers and nephrotoxicity. Clinical Nephrotoxins. 2nd ed. Massachusetts: Kluwer Academic Publishers; 2003:621-55.

11. Galley HF. Can acute renal failure be prevented? J R Coll Surg Edinb. 2000;45(1):44-50.

12. Perazella MA. Drug-induced nephropathy: an update. Expert Opin Drug Saf. 2005;4(4):689-06.

13. Mingeot-Leclercq MP, Tulkens PM. Aminoglycosides: Nephrotoxicity. Antimicrob Agents Chemother. 1999;43(5):1003-12.

14. Banday AA, Farooq N, Priyamvada S, Yusufi AN, Khan F. Time dependent effects of gentamicin on the enzymes of carbohydrate metabolism, brush border membrane and oxidative stress in rat kidney tissues. Life Sci. 2008;82(9-10):450-9.

15. Naughton CA. Drug induced nephrotoxicity. Am Fam Physician. 2008;78(6):743-50.

16. Karahan I, Atessahin A, Yilmaz S, Ceribasi AO, Sakin F. Protective effect of lycopene on gentamicininduced oxidative stress and nephrotoxicity in rats. Toxicol. 2005;215(3):198-04. 
17. Soliman KM, Abdul-Hamid M, Othman AI. Effect of carnosine on gentamicin-induced nephrotoxicity. Med Sci Monit. 2007;13(3):73-83.

18. Kore KJ, Shete RV, Jadhav PJ. RP-HPLC method of simultaneous nephroprotective role of A. marmelos extract. IJRPC. 2011;1(3):617-23.

19. Devi PS, Shyamala DC. Protective effect of quercetin in cisplatin induced cell injury in the rat kidney. Indian J Pharmacol. 1999;31(6):422-6.

20. Arunkumar PA, Viswanatha GL, Radheshyam N, Mukund H, Belliyappa MS. Science behind cisplatininduced nephrotoxicity in humans: A clinical study. Asian Pac J Trop Biomed. 2012;2(8):640-4.

21. Neeraj KG, Sharad M, Tejram S, Abhinav M, Suresh PV, Rajeev KT. Evaluation of anti-apoptotic activity of different dietary antioxidants in renal cell carcinoma against hydrogen peroxide. Asian Pac J Trop Biomed. 2011;2(8):57-63.

22. Ali BH, Al-Wabel N, Mahmoud O, Mousa HM, Hashad M. Curcumin has a palliative action on gentamicin-induced nephrotoxicity in rats. Fund Clin Pharmacol. 2005;19(4):473-7.

23. Maldonado PD, Barrera D, Medina-Campos ON, Hernandez-Pando R, Ibarra-Rubio ME, PedrazaChaverri J. Aged garlic extract attenuates gentamicin induced renal damage and oxidative stress in rats. Life Sci. 2003;73(20):2543-56.

24. Sener G, Sehirli AO, Altunbas HZ, Ersoy Y, Paskaloglu K, Arbak S, et al. Melatonin protects against gentamicin-induced nephrotoxicity in rats. J Pineal Re. 2002;32(4):231-6.

25. Erdem A, Gundogan NU, Usubutun A, Kilinc K, Erdem SR, Kara A, et al. The protective effect of taurine against gentamicin-induced acute tubular necrosis in rats. Nephrol Dial Transplant. 2000;15(8):1175-82.

26. Sivakumar V, Dhanrajan MS, Riyazullah MS. Preliminary phytochemical screening and evaluation of free radical scavenging activity of Tinospora cordifolia. Int J Pharm Pharm Sci. 2010;2(4):186-8.

27. Reddy SS, Ramatholisamma P, Karuna R, Saralakumari D. Preventive effect of Tinospora cordifolia against high-fructose diet-induced insulin resistance and oxidative stress in male Wistar rats. Food Chem Toxicol. 2009;47(9):2224-9.

28. Rawal A, Muddeshwar M, Biswas S. Effect of Rubia cordifolia, Fagonia cretica linn, and Tinospora cordifolia on free radical generation and lipid peroxidation during oxygen-glucose deprivation in rat hippocampal slices. Biochem Biophys Res Commun. 2004;324(2):588-96.

29. Kumar V, Modi PK, Saxena KK. Exploration of hepatoprotective activity of aqueous extract of Tinospora cordifolia - An experimental study. Asian J Pharm and Clin Res. 2013:6(1):87-91.

Cite this article as: Sharma M, Pundir J, Vishwakarma P, Goel RK, Saini M, Saxena KK. Evaluation of nephroprotective activity of Tinospora cordifolia against gentamicin induced nephrotoxicity in albino rats: an experimental study. Int J Basic Clin Pharmacol 2019;8:1179-84. 